\title{
INOVASI PRODUK SAMBAL LINGKUNG BERBASIS TEKNOLOGI SEBAGAI UPAYA PENINGKATAN USAHA UMKM KECAMATAN PELAYANGAN KOTA JAMBI
}

\author{
Agus Solikhin ${ }^{1}$, Husni Hasbullah ${ }^{2}$, Yayuk Sriayudha ${ }^{3}$, Ade Perdana Siregar ${ }^{4}$ \\ ${ }^{1}$ Fakultas Ekonomi dan Bisnis Universitas Jambi \\ ${ }^{2}$ Fakultas Ekonomi dan Bisnis Universitas Jambi \\ ${ }^{3}$ Fakultas Ekonomi dan Bisnis Universitas Jambi \\ ${ }^{4}$ Fakultas Ekonomi dan Bisnis Universitas Jambi
}

agus.slk09@gmail.com, husni.hasbullah.unja@gmail.com, yayuk.sriayudha@unja.ac.id, ade.perdana@unja.ac.id

\begin{abstract}
ABSTRAK
Pengembangan produk khas daerah memberikan peluang bagi UMKM dalam peningkatan usaha. Sambal lingkung merupakan salah satu produk khas daerah Jambi yang terbuat dari ikan. Rasa yang lezat dan gurih menjadikan produk sambal lingkung memiliki potensi untuk dikembangkan. Pada kegiatan ini yang menjadi mitra adalah Kelompok Usaha Deniz dan Kelompok Usaha Mutiara Indah Bersama di Kecamatan Pelayangan Kota Jambi. Permasalahan mitra yang menjadi prioritas untuk diatasi adalah kontinuitas bahan baku masih rendah, produksi belum rutin, penerapan teknologi produksi masih rendah dan manajemen usaha. Kegiatan ini bertujuan meningkatkan usaha UMKM melalui inovasi produk khas daerah sambal lingkung pada aspek produksi, teknologi dan manajemen. Pencapaian tujuan dilakukan menggunakan metode sosial dan pastisipasif dengan memberikan bantuan berupa teknologi tepat guna dan pelatihan serta pendampingan dalam manajemen usaha. Pelaksanaan metode menghasilkan peningkatan yang baik, mitra telah berkerjasama dengan pemasok ikan agar kontuinitas bahan baku meningkat. Pemberian bantuan teknologi tepat guna berupa alat spinner dan mesin pengaduk ikan, dapat meningkatkan produksi mitra secara rutin dan baik. Melalui pelatihan dan pendampingan manajemen usaha, mitra dapat menciptakan kemasan yang baik dan menarik serta dapat menyusun laporan keuangan.
\end{abstract}

Kata kunci : Inovasi, Teknologi Tepat Guna, Manajemen

\section{PENDAHULUAN}

Perkembangan dunia usaha di Provinsi Jambi pada saat ini masih di dominasi dengan Usaha Kecil Menengah (UKM). Berdasarkan hasil Sensus Ekonomi 2016, jumlah UKM mencapai lebih 311.000 usaha atau 98,90 persen dari total usaha non pertanian di Provinsi Jambi. Kota Jambi sebagai Ibu Kota Provinsi Jambi menjadi pusat pergerakan ekonomi di Provinsi Jambi. Pada tahun 2017 jumlah UKM di Kota Jambi mencapai 19,27 persen dari 11 Kabupaten/Kota yang selanjutnya diikuti Kabupaten Merangin, Kabupaten Bungo dan Kabupaten Tebo merupakan tiga wilayah dengan jumlah UKM mendekati 10 persen di Provinsi
Jambi, untuk persentasi secara keseluruhan dapat dilihat pada tabel berikut

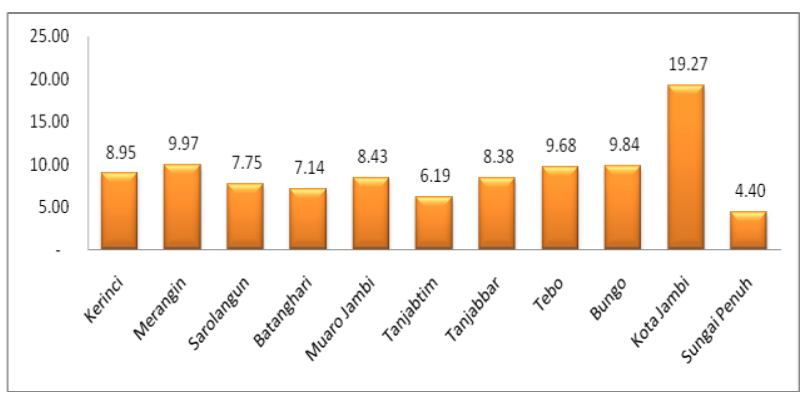

Gambar 1 Persentasi UKM per Kabupaten/ Kota di Provinsi Jambi Tahun 2017 
Kota Jambi merupakan Ibu Kota Provinsi Jambi, yang terdiri dari 11 Kecamatan. Salah satu kecamatan di Kota Jambi yang banyak terdapat UKM adalah di Kecamatan Pelayangan. Lokasinya terpisahkan oleh sungai Batanghari dari Kota Jambi, sehingga letaknya berada di seberang Kota Jambi, sementara jarak dengan Universitas Jambi adalah 14 Km dan dengan waktu tempuh 33 menit.Menurut BPS Kota Jambi (2018), di Kecamatan Pelayangan memiliki industri rumah tangga berjumlah 211 dan industri besar / sedang berjumlah 3, maka jenis usaha terbanyak di Kecamatan Pelayangan adalah industri rumah tangga. Mata pencaharian utama masyarakat Kecamatan Pelayangan adalah bertani dan berdagang. Luas wilayah Kecamatan Pelayangan adalah 15,29 Km dengan kepadatan penduduk 862 orang $/ \mathrm{Km}^{2}$ dan terdiri dari 6 Kelurahan yaitu Kelurahan Tengah, Kelurahan Jelmu, Kelurahan Mudung Laut, Kelurahan Arab Melayu, Kelurahan Tahtul Yaman dan Kelurahan Tanjung Johor.

Berdasarkan pengamatan Kecamatan Pelayangan Kota Jambi merupakan sentra penghasil makanan olahan ikan. Lokasinya yang terletak di tepi sungai Batanghari menjadikan daerah ini banyak menghasilkan jenis-jenis produk makanan berbahan dasar ikan seperti kue-kue tradisional, kerupk ikan, abon ikan dan salah satunya sambal lingkung. Sambal lingkung adalah sambal kering yang terbuat dari ikan melalui proses sangrai tanpa menggunakan minyak. Produk sambal lingkung ini memiliki potensi untuk dikembangkan sebagai salah satu oleh-oleh khas Jambi karena razanya yang lezat, gurih dan keberadaanya yang belum ada di daerah lain. Namun disayangkan suatu usaha terpadu antar UKM, pemerintah dan pengusaha untuk mengembangkan produk sambal lingkung. Meskipun telah diproduksi oleh terbentuk beberapa kelompok usaha, namun hanya beberapa kelompok yang konsisten dan kontiniu untuk memproduksi sambal lingkung. Melalui kegiatan ini diupayakan adanya inovasi produk sambal lingkung berbasi teknologi sebagai upaya peningkatan usaha UMKM di kecamatan Pelayangan.

Mitra dalam kegiatan ini ada dua yaitu Kelompok Usaha Mutiara Indah Bersama dan Kelompok Usaha Daniz di Kelurahan Tengah Kecamatan Pelayangan Kota Jambi. Ketua Kelompok usaha Mutiara Indah Bersama adalah
Zumratul Aini dengan anggota kelompok 11 orang. Ketua kelompok memiliki pendidikan SMA sementara latar belakang pendidikan anggota beragam yaitu SMP dan SMA. Kelompok usaha ini berdiri tahun 2008 dan belum memiliki izin usaha. Mitra juga belum memiliki paten dalam hal proses produksi dan TTG yang digunakan. Kelompok usaha ini juga belum pernah mengikuti pelatihan maupun pendamping dari instansi pemerintah maupun swasta. Kelompok Usaha Daniz lebih maju dari Kelompok Usaha Mutiara Indah Bersama. Ketua Kelompok Usaha Daniz adalah Rahmawati dan telah berdiri sejak 2011 dengan jumlah anggota 11 orang. Latar belakang pendidikan SDM dikelompok ini beragam mulai dari SMP dan SMA namun pendidikan tertinggi adalah sarjana. Ketua Kelompok Usaha Daniz berpendidikan Strata Satu (S1) dalam bidang Pertanian. Beberapa kegiatan pelatihan telah sering diikuti oleh ketua Kelompok Usaha Daniz baik oleh Pemerintah Provinsi, Kota Jambi maupun swasta melalui program CSR, namun mitra juga belum memiliki paten dalam hal proses produksi dan TTG yang digunakan.

Kedua kelompok sama-sama memproduksi sambal lingkung namun kelompok Daniz lebih konsisten dan kontinu dalam memproduksi dikarenakan kelompok usaha Mutiara Indah Bersama juga memproduksi jenis usaha lain yaitu kue-kue tradisional khas Kecamatan Pelayangan.

Kedua mitra berada di Kecamatan Pelayangan dengan akses yang dekat ke jalan raya. Saluran distribusi untuk pemasaran sambal lingkung belum jelas. Produksi hanya dilakukan untuk konsumsi pribadi dan pesanan. Pesanan yang rutin dilakukan adalah ketika musim haji. Sambal lingkung di pesan jamaah haji dalam jumlah banyak untuk dibawa sebagai makanan persediaan selama di tanah suci. Produk sejenis sudah ada dipasarkan ke swalayan besar namun dengan kemasan dan merek "Sambal Lingkung Amanah" berasal dari luar Kecamatan Pelayangan. Berdasarkan observasi, idel awal dan resep sambal lingkung tersebut berasal dari Rahmawati Ketua Kelompok Usaha Daniz yang masih memiliki hubungan kekerabatan. Namun sayangnya produk tersebut telah lebih dahulu dipasarkan oleh UMKM lain.

Kedua mitra menjalankan usaha dengan manajemen sederhana meliputi perencanaan,

$$
\text { Teknologi Tepat Guna }
$$


pengorganisasian, pengarahan dan pengawasan. Perencanaan didasarkan pada intuisi dan bersifat jangka pendek. Belum ada perencanaan manajerial yang tersusun secara dokumen dan berjangka waktu. Pembagian kerja juga masih bersifat kekeluargaan. Pencatatan keuangan telah dilakukan, namun belum terbiasa untuk membuat pencatatan secara rutin dan rapi sehingga buku kas umum ada tetapi tidak diisi dengan baik sesuai dengan kaidah akuntansi. Audit laporan keuangan belum pernah dilakukan. Mitra belum memahami tentang ketentuan dalam perpajakan. Pola manajemen yang diterapkan tergolong kepada kekeluargaan dan dalam penerapannya sangat kental dengan nuansa budaya sebagai kearifan lokal. Modal berasal dari modal pribadi dan keluarga. Uang hasil penjualan sambal lingkung dikelola dengan cara yang sederhana yaitu dengan mengumpulkan hasil ke bendahara kelompok, lalu masing-masing dihitung beban kerja dan dibayarkan sesuai dengan beban kerja. Modal menjadi salah satu kendala utama yang dihadapi mitra selain kendala manajemen dan produksi. Mitra belum ingin menggunakan sumber pembiayaan dari perbankan untuk memenuhi kebutuhan modal karena kurang pemahaman mitra dan budaya 'takut berhutang'.

Pemasaran sambal lingkung masih fokus pada pesanan dan belum menghasilkan produk sesuai dengan keinginan konsumen. Produk masih dibuat untuk kepentingan event dan bazaar. Promosi dilakukan karena masyarakat sebagian besar belum mengetahui produk tersebut. jika dilihat sekilas masyarakat menganggap sambal lingkung adalah abon atau serundeng Produk Sambal lingkung dijual dengan harga Rp. 23.000,- per ons. Saat ini produk sambal lingkung belum menjadi oleh-oleh yang banyak diinginkan konsumen ketika datang ke Kota Jambi. Hal inilah yang menjadi salah satu ketertarikan dan motivasi Tim pelaksana untuk meningkatkan usaha sambal lingkung sebagai produk kuliner khas Kota Jambi

Permasalahan mitra dapat diidentifikasi sebagai berikut; 1) Kesinambungan pengadaan bahan baku. Bahan baku utama untuk produksi sambal lingkung adalah ikan patin . Mitra membeli bahan baku ikan dari pasar dan nelayan di sekitar lokasi usaha. Belum ada perjanjian kerjasama antara mitra dengan pemasok ikan, sehingga kontinuitas bahan baku masih rendah; 2) Produksi berdasarkan pesanan. Produksi sambal lingkung didasarkan pada pesanan dari konsumen, mitra belum secara rutin memproduksi sambal lingkung. Kalau persediaan masih banyak mitra tidak memproduksi sambal lingkung. Sistem produksi secara pesanan menyebabkan perputaran penjualan produk menjadi rendah; 3) Pencatatan keuangan. Manajemen usaha dikelola kelompok dengan sistem manajemen yang masih sederhana. Buku kas umum sudah ada namun tidak diisi secara rutin. Kurangnya pemahaman bendahara untuk mengisi pos-pos dalam neraca keuangan; 4) Saluran distribusi. Distribusi produk melalui saluran langsung dan tidak langsung yaitu melalui pengecer dan mini market, belum masuk ke swalayan karena akses informasi dan lobi yang masih lemah; 5) Kemasan dan labeling. Kedua mitra telah memiliki ijin usaha, PIRT dan sertifikat halal, namun belum dimanfaatkan secara maksimal. Pada kemasan belum dicantumkan label halal dan daerah pemasaran masih belum luas. Produk sambal lingkung belum dikenal sebagai produk khas Kota Jambi karena promosi yang masih kurang meskipun kedua mitra telah memiliki facebook dan website di pasar online. Lemahnya pemahaman dan keterampilan mitra terkait dengan pemahaman teknologi sebagai sarana promosi; 6) Pemanfaatan teknologi tepat guna. Kedua mitra belum memiliki berbagai peralatan untuk proses produksi sambal lingkung. Mitra memerlukan mesin spinner untuk saat ini dan inovasi baru agar sambal lingkung lebih meningkat kualitasnya.

\section{METODE}

Permasalahan yang diperoleh berdasarkan survei dan diskusi antara tim dengan mitra menunjukan bahwa mitra berpartisipasi besar dalam hal ini. Tim pelaksana hanya berperan sebagai fasilitator dan dinamisator untuk memberikan motivasi dan bantuan ilmu pengetahuan dan teknologi kepada mitra. Bentuk keterlibatan itu antara lain bersama tim menentukan waktu dan tempat pelaksanaan. Berkomunikasi secara aktif dengan tim sehingga permasalahan yang timbul dapat diketahui dengan cepat. Kooperatif dalam mengurus keperluan administrasi dan usaha seperti mendatangi dinas kesehatan untuk mendapatkan kelayakan makanan yang sehat dan bersih, dinas

$$
\text { Teknologi Tepat Guna }
$$


koperasi untuk mendapatkan informasi tentang bantuan yang dapat diperoleh dan sebagainya.

Pelaksanaan kegiatan pengabdian kepada masyarakat ini menggunakan metode pendekatan sosial dan partisipatif. Pendekatan ini berfungsi untuk menumbuhkan kemandirian mitra dalam penyelesaian masalah yang dihadapi dengan mendapatkan bantuan dari Perguruan Tinggi. Tim Pengabdian kepada masyarakat meninjau dan berkomunikasi secara intensif dengan mitra dan memberikan motivasi kepada mitra untuk lebih tumbuh dan mengatasi masalah. Harapan dari kegiatan ini, mitra dapat mandiri dalam menjalankan usahanya saat menghadapi masalah, dengan demikian tim pengabdian kepada masyarakat memilih metode dalam bentuk pelatihan dan pendampingan dari aspek produksi, teknologi dan manajemen

Perencanaan kegiatan yang disusun adalah sebagai berikut; 1) Persiapan, langkah-langkah yang akan dilakukan pada persiapan untuk dilaksanakan kegiatan pengabdian ini adalah; a) tim menggali informasi permasalahan yang ada pada mitra dengan menjalin komunikasi untuk menyatukan pendapat sehingga dapat merumuskan masalah yang pada mitra; b) Tim berkoordinasi dengan Pemerintah Kota Jambi, pihak pemerintahan Kecamatan Pelayangan Kota Jambi dan perangkat desa, tujuan untuk memberitahu bahawa adanya kegiatan pengabdian yang dilaksanakan pada daerah mereka dan untuk kepentingan dokumen administrasi yang berhubungan dengan pemerintah setempat; c) Tim pelaksana yang ditugaskan oleh Universitas Jambi mempersiapkan administrasi terkait dengan perijinan dan surat tugas melalui lembaga penelitian dan pengabdian kepada masyarakat.Tim pela ksana menjalin komunikasi dengan tenaga ahli dari Universitas Jambi yang memiliki keahlian untuk mengatasi permasalahan mitra pada aspek produksi, teknologi dan manajemen; d) Mempersiapkan mahasiswa untuk membantu pelaksanaan kegiatan. Mahasiswa yang ikut serta dalam kegiatan berjumlah 5 orang yaitu mahasiswa Fakultas Ekonomi dan Bisnis Universitas Jambi. Mahasiswa akan dilibatkan dalam pelatihan, pemantauan perkembangan mitra dan dokumentasi kegiatan; 2) Pelaksanaan, kegiatan pelaksanaan melakukan kegiatan sesuai dengan solusi yang direncanakan, langkah-langkah yang akan dilakukan adalah memfasilitasi mengadakan pertemuan dengan pihak-pihak untuk kesediaan berkerja sama dengan mitra terutama pemasok dan pengecer serta mendiskusikan bentuk kerja sama, melakukan kegiatan untuk meningkatkan pemahaman dan keterampilan mitra melalui pelatihan dan pendampingan pada bidang manajemen. Kegiatan tersebut meliputi penyusunan laporan keuangan sederhana, mendesain kemasan dan mempromosikan produk melalui iklan dan promosi penjualan secara online dan offline serta memberikan pelatihan dan pendampingan terhadap pemanfaatan sumber-sumber pembiayaan sebagai modal usaha serta pemahaman tentang aspek legalitas usaha, memberikan pelatihan dan pendampingan dengan mendatangkan narasumber untuk meningkatkan penguasaan teknologi pada proses produksi dan pemasaran, menerapkan teknologi tepat guna dengan memberikan bantuan berupa peralatan pengering spiner dan mengoptimalkan pemanfaatan mesin blander ikan; 3) Pemantauan yaitu meliputi pemantauan kerjasama mitra dengan pemasok bahan baku dan pengecer sambal lingkung, pemantauan terhadap pengembangan inovasi produk pada kemampuan mitra mendesain merek, label, dan memperbaiki kemasan, pemantauan penggunaan tekhnologi tepat guna pengering spinner dan mesin blander ikan. Memantau kemampuan mesin untuk mempercepat proses produksi dan menghasilkan produk yang berkualitas, pemantauan terhadap kegiatan promosi yang dilakukan oleh mitra, pemantauan terhadap pelatihan penyusunan laporan keuangan sederhana untuk melihat perubahan perilaku mitra dan membandingkan dokumen pembukuan sebelum dan sesudah pelaksanaan PPM, pemantauan terhadap kemampuan mitra memanfaatkan sumber-sumber pembiayaan sebagai modal usaha. 4) Evaluasi yaitu meliputi evaluasi terhadap kemampuan mitra menjalin kerjasama dengan pemasok dan pengecer, evaluasi tentang kemampuan mitra meningkatkan kualitas produk dan daya tahan produk, evaluasi pelatihan penyusunan laporan keuangan mitra agar pengelolaan usaha lebih professional, evaluasi terhadap keberadaan merek, label dan kemasan, evaluasi terhadap kegiatan promosi yang dilakukan oleh mitra, evaluasi kualitas tekhnologi tepat guna pengering spinner dan mesin blander ikan untuk mengatasi permasalahan mitra dari aspek produksi, dan penyusunan laporan pelaksanaan kegiatan PPM. 


\section{HASIL DAN PEMBAHASAN}

\section{Kegiatan Pengabdian kepada Masyarakat}

Kegiatan pengabdian kepada masyarakat sebagai upaya memberikan solusi untuk mengatasi permasalahan mitra, diawali dengan tahapan persiapan kegiatan yaitu melakukan rapat koordinasi tim dalam rangka penyusunan jadwal kegiatan, penentuan narasumber, pembagian tugas untuk anggota tim. Kesimpulan dari hasil rapat, maka tim melakukan koordinasi dengan mitra mengenai rincian kegiatan dan persiapan peralatan dan perlengkapan dalam kegiatan yang meliputi, persiapan administrasi, pembelian alat teknologi tepat guna, pembelian dan desain kemasan untuk produk serta spanduk dan konsumsi untuk pelatihan dan pendampingan.

Pada tahap pelaksanaan dilakukan sesuai dengan solusi yang direncanakan, diawali dengan pemberian bantuan alat teknologi tepat guna kepada mitra berupa alat pengering minyak (spinner), alat pengaduk ikan (blander) dan timbangan digital.

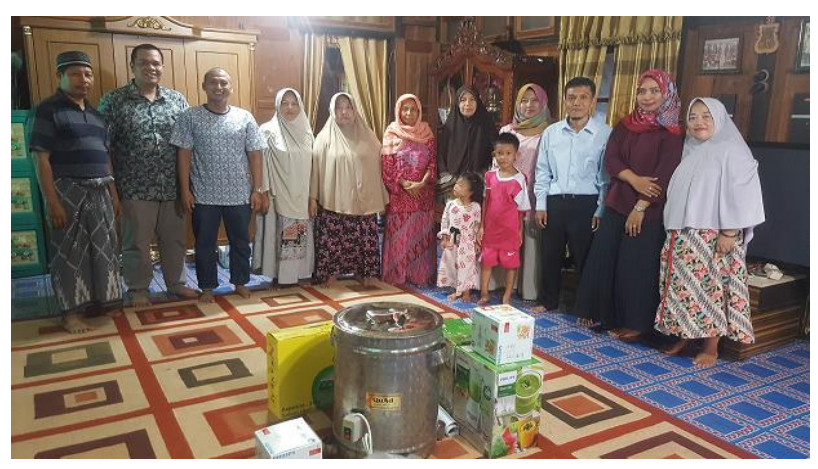

Gambar 2 Pemberian bantuan alat TTG

Spinner berfungsi untuk mengeringkan minyak sebagai pengganti kertas roti (kertas minyak) yang sebelumnya digunakan oleh mitra, agar proses pengeringan minyak pada sambal lingkung lebih cepat dan higienis maka alat ini sangat diperlukan. Blander berfungsi memberikan solusi kepada mitra sebagai alat pengaduk ikan yang selama ini dilakukan secara manual. Timbangan digital diberikan agar produk pada setiap kemasan memiliki berat yang standar, yang sebelumnya dikemas hanya dengan perkiraan. Selain dalam pemberian alat, tim pengabdian kepada masyarakat memberikan masukan kepada mitra mengenai kerjasama untuk pemasok bahan baku ikan. Harga bahan baku ikan berpengaruh terhadap kondisi sungai, jika air sungai mengalami surut maka harga ikan akan menjadi lebih tinggi. Selanjutnya, dilakukan pendampingan proses produksi sambal lingkung dimana proses produksi dilakukan selama 7 jam. Pendampingan ini mitra diarahkan untuk menggunakan alat yang sudah diberikan sebelumnya. Proses produk dapat dilihat sebagai berikut :

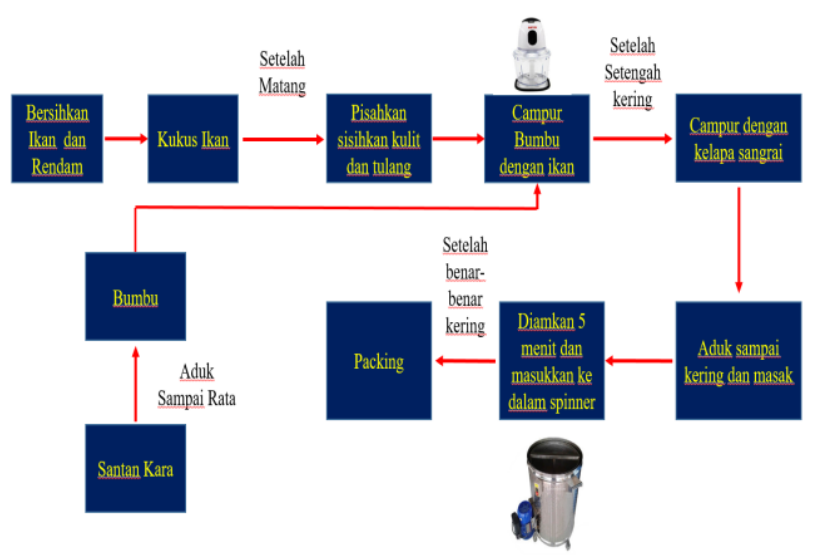

\section{Gambar 3 Proses Produksi Sambal Lingkung}

Proses produksi dimulai dengan membersihkan ikan dan merendam ikan dengan air cuka selama 5 menit, kemudian ikan dikukus dengan daun serai, salam dan daun jeruk sampai matang. Sementara menunggu matang menyiapkan bumbu dan bumbu digiling serta menyiapkan kelapa sangria. Bumbu dimasukan santan kara dan diaduk sampai rata. Ikan yang sudah matang dipisahkan antara kulit dan tulangnya, kemudian ikan yang sudah matang masukan ke dalam bumbu dan diaduk. Dalam mengaduk ikan digunakan alat yang telah diberikan berupa blander. Penggunaan blander sangat membantu dari proses mengaduk, dapat mempercepat dari proses tersebut. Setelah setengah kering masukan kelapa sangria, garam dan gula kemudian diaduk sampai kering dan masak. Diamkan 5 menit dan masukkan ke dalam spinner atau alat pengering yang diberikan. Alat berfungsi untuk membuat minyak benar-benar menjadi kering yang sebelumnya mengandalkan kertas minyak. Fungsi menggunakan alat spinner, proses pembuatan menjadi lebih cepat dan produk terlihat 
higienis dan bersih. Setelah benar-benar kering sambal lingkung siap untuk dipacking

Pelatihan dan praktek untuk manajemen usaha. Materi yang disampaikan pada pelatihan ini pertama dimulai dengan pemahaman mengenai desain dari suatu merek. Materi yang diberikan kepada mitra diawali dengan pemahaman mendesain merek agar lebih menarik dan penyampaian informasi yang tepat terkandung pada merek. Tim pengabdian kepada masyarakat melakukan pendampingan untuk desain merek, merek yang didesain oleh tim dapat dilihat pada gambar berikut :

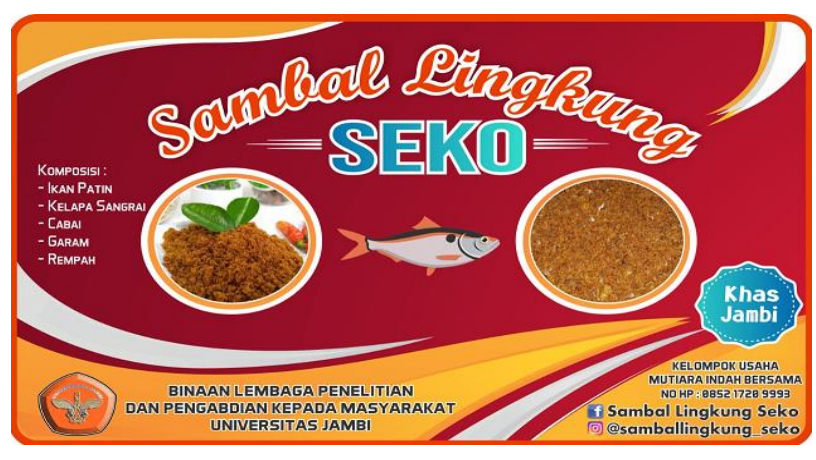

\section{Gambar 4 Merek Produk}

Desain yang dibuat dengan tampilan yang lebih menarik dan adanya penyampaikan informasi yang jelas mengenai produk tersebut, dimana adanya nama kelompok usaha dan identitas dari mitra yang dapat dihubungi, terlebih pada merek tersebut menegaskan bahwa produk merupakan khas daerah Jambi. Penjelasan mengenai informasi yang terdapat pada merek sangat membantu mitra dalam melakukan kegiatan promosi. Melanjutkan pelatihan dan pendapingan ini, mitra juga diberikan pemahaman mengenai konsep pemasaran dengan media sosial. Pada praktek menjalankan pemasaran digital. Materi yang disampaikan pada tahapan ini, pembuatan media sosial dan cara menggunakan media sosial tersebut untuk kegiatan promosi. Media sosial merupakan media yang digunakan untuk kegiatan promosi dengan biaya yang sangat kecil, maka dengan adanya pelatihan dan praktek ini diharapkan mitra dapat secara rutin melakukan kegiatan promosi. Materi selanjutnya, mitra diberikan pemahaman mengenai kemasan yang menarik. Tim pengabdian kepada masyarakat membantu mitra dalam membuat kemasan.
Kemasan yang disarankan kepada mitra ada dua jenis, dapat dilihat pada gambar berikut :

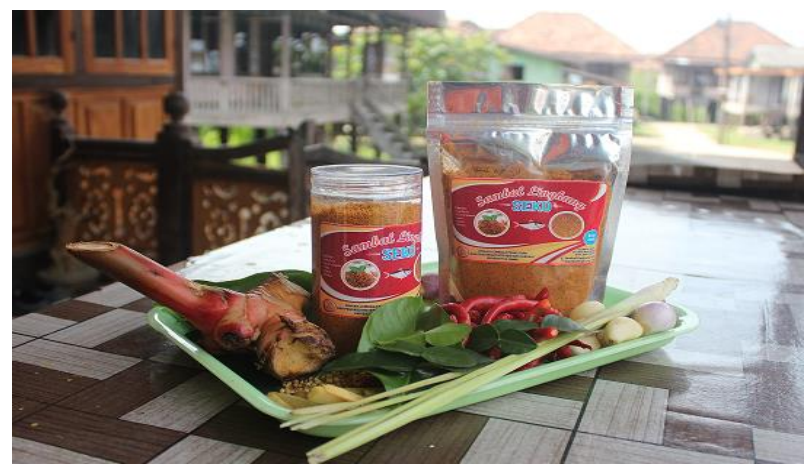

Gambar 5 Kemasan Produk

Kemasan hasil pelatihan dan praktek ini sudah mempunyai standar berat dari produk yaitu 150 gram untuk setiap produk. Kemasan dibuat dalam 2 bentuk yang disesuaikan dengan kebutuhan dari konsumen. Hal penting bagi produk makanan yaitu produk terlihat higienis bersih dan rapih serta produk diberikan merek sebagai identitas dan penyampaikan informasi. Materi yang terakhir merupakan materi yang berhubungan dengan keuangan.Mitra diberikan materi dalam pembuatan laporan keuangan serta cara menghitung harga pokok produksi untuk menentukan harga jual. Materi yang disampaikan secara sederhana sebagai analisis dasar untuk mitra pada tahap awal mengelola keuangan.

Pasca dilakukan kegiatan pengabdian kepada masyarakat berupa pemberian alat, pelatihan dan pendampingan, maka tim pengabdian kepada masyarakat melakukan pemantauan terhadap mitra. Penggunaan teknologi tepat guna berupa alat spinner dan blander tetap berjalan dengan lancar, mitra lebih dengan cepat melakukan proses produksi sehingga dapat memenuhi kebutuhan pasar akan tersedianya produk yang siap untuk dijual. Kegiatan promosi tetap dilakukan oleh mitra, disamping itu mitra tetap konsisten dalam perbaikan terhadap kemasan. Penyusunan laporan keuangan sederhana dan perhitungan harga pokok produk tetap dilakukan oleh mitra sehingga mitra dapat dengan lebih cepat menentukan harga jual.

Evaluasi yang dilakukan terhadap pelaksanaan kegiatan pengadian kepada masyarakat, mitra mendapatkan solusi untuk menjawab permasalahan Teknologi Tepat Guna 
yang selama ini menjadi penghambat dalam menjalankan usaha. Teknologi tepat guna dapat membantu mitra melakukan proses produksi lebih cepat dan produk yang dihasilkan terlihat lebih higienis. Kemampuan mitra dalam kegiatan promosi meningkat dan mitra dapat mengemas produk sambal lingkung sesuai standar produk dan menarik. Kemampuan mitra dalam membuat laporan keuangan dan perhitungan harga pokok produksi meningkat, sehingga saat ini mitra dapat menentukan harga jual lebih cepat dan tepat.

\section{Hasil Kegiatan Pengabdian kepada Masyarakat}

Pelaksanaan kegiatan pengabdian kepada masyarakat yang dilaksanakan dapat memberikan solusi pada permasalahan yang dihadapi mitra. Pemberian alat teknologi tepat guna dapat membantu mitra dalam menjalankan proses produksi dan berat produk per kemasan memiliki standar. Penjelasan materi pada pelatihan dan pendampingan dapat dipahami oleh mitra dengan baik. Mitra sangat antusias dalam pelaksanaan kegiatan ini, terlihat dari keaktifan mitra dalam berdiskusi dan kegiatan praktek. Desain yang menarik memberikan kesan tersendiri bagi konsumen dan akan menumbuhkan minat beli. Kemasan yang baik memberikan kepercayaan kepada konsumen bahwa produk higienis, bersih dan rapih. Tersedianya media sosial sebagai sistem yang dibentuk dalam kegiatan promosi sangat membantu mitra dikarenakan tidak membutuhkan biaya yang terlalu tinggi. Promosi melalui media sosial dapat menyampaikan informasi mengenai produk tepat dan cepat pada target konsumen. Pemahaman mitra dalam membuat laporan keuangan dan perhitungan harga pokok produksi dapat membantu mitra dalam mengambil keputusan pengembangan usaha dan penentuan harga jual. Tersedianya bahan baku ikan terhadap pembuatan produk sambal lingkung masih dapat terjaga, hanya perlu dilakukan kerjasama dengan beberapa pemasok bahan baku ikan jika produksi akan dilakukan secara kontinu dalam skala besar. Mitra dari sisi lain perlu dikembangkan kreatifitas dan inovasi dalam pengembangan produk untuk memenuhi kebutuhan pasar dan menghadapi pesaing.

\section{Luaran yang dicapai}

Luaran dari kegiatan pengabdian kepada masyarakat yang telah dilakukan sebagai berikut; 1) Tersedianya alat teknologi tapat guna pada mitra berupa spinner, blander dan timbangan digital sebagai pendukung proses produksi mitra dan pengembangan pengetahuan mitra terhadap teknologi; 2) Tersedianya kemasan yang baik agar produk terlihat higienis, bersih dan rapih; 3) Tersedianya merek yang menarik dan penyampaikan informasi lengkap mengenai produk sebagai upaya peningkatan omzet pada mitra; 3) Tersedianya media sebagai pendukung sistem promosi melalui digital berupa media sosial instagram dan facebook agar mitra dapat melakukan kegiatan promosi dengan biaya yang tidak tinggi; 4) Meningkatnya pemahaman mitra dalam melakukan promosi melalui media sosial dan pemahaman mitra mengenai manajemen keuangan sehingga dapat menyusun laporan keuangan sederhana dan perhitungan harga pokok produksi

\section{KESIMPULAN}

Kegiatan pengabdian kepada masyarakat telah dilaksanakan sesuai dengan rencana awal. Mitra memberikan respon yang positif pada kegiatan ini. Pemberian alat teknologi tepat guna berupa alat pengering minyak (spinner), alat pengaduk ikan (blander) dan timbangan digital dapat membantu mitra dalam proses produksi dan menjadikan produk memiliki standar berat per kemasan. Ketersediaan bahan baku menjadi faktor pendukung berjalannya program ini pada pendampingan proses produksi. Pelatihan dan pendampingan mengenai manajemen usaha dapat meningkatkan pemahaman mitra pada menajemen pemasaran dan manajemen keuangan, respon positif dan antusias mitra sangat mendukung kegiatan ini berjalan dengan baik.

Pengembangan produk khas daerah memiliki potensi yang besar. Keberlanjutan dari hasil kegiatan ini, perlu adanya pendampingan terhadap mitra untuk meningkatkan motivasi dan kreatifitas mitra dalam pengembangan produk serta dukungan dari pihak pemerintah dalam pengembangan usaha untuk industri produk khas daerah 


\section{UCAPAN TERIMAKASIH}

Pelaksanaan kegiatan pengabdian kepada masyarakat mendapat bantuan dari Universitas Jambi, sehingga dapat terlaksana dengan baik. Terima kasih disampaikan kepada Universitas Jambi yang telah memberikan bantuan dan dukungan

\section{REFERENSI}

Badan Pusat Statistik (2018), Kecamatan Pelayangan dalam Angka 2018, BPS Kota Jambi

Badan Pusat Statistik (2018), Potensi Usaha Mikro Kecil Provinsi Jambi, BPS Provinsi Jambi
Eikebrokk,Tom R dan Olsen,Dag H, 2009. Training, Competence and Business Performance:Evidence from E-business in European Small and Medium-Sized Enterprises. International Journal of EBusiness Research. Vol.5,No.1.p.92-116.

Octavia, Ade., Sriayudha, Yayuk, Perdana, Ade., \&Widiatuti, Fitri (2018).Peningkatan Daya Saing Produk Unggulan Daerah Melalui Kegiatan Pelatihan Dan Pendampingan Usaha Kerupuk Ikan Di Kecamatan Pelayangan Seberang Kota Jambi. EProsiding PKMCSR.

Tambunan,Mangara, 2009. Melangkah Ke Depan UMKM Dalam Perekonomian Indonesia di Masa Depan, Makalah Pada Debat Ekonomi ISEI. 